\title{
Jurist-Diction
}

Volume 4 No. 2, Maret 2021

\section{Gagasan Mekanisme Pengisian Jabatan Presiden dan Wakil Presiden Ketika Keadaan Darurat}

\author{
Aditya Wahyu Saputro dan Mayang Devi Azhara \\ aditya.wahyu81@ui.ac.id \\ Universitas Indonesia
}

\begin{abstract}
How to cite:
Aditya Wahyu Saputro dan Mayang Devi Azhara

'Gagasan Mekanisme

Pengisian Jabatan Presiden dan

Wakil Presiden Ketika Keadaan

Darurat' (2021) Vol. 4 No. 2

Jurist-Diction
\end{abstract}

Histori artikel:

Submit 4 Januari 2021;

Diterima 18 Februari 2021;

Diterbitkan 1 Maret 2021.

DOI:

10.20473/jd.v4i2.25747

p-ISSN: $2721-8392$

e-ISSN: 2655-8297

\section{Abstract}

An emergency such as a pandemic or war prevents the administration of the state from being maximally carried out, such as direct elections. Therefore, state of emergency law (etat de siege) is needed as a prevention fo emergency, especially regarding electing Indonesia's president and vice president. Emergency provisions are needed amid a future pandemic threat and Indonesia's geographic position which is prone to disasters has the potential to hinder the transfer of power through general elections. It was concluded that, when a state emergency has been proclaimed by the president, the mechanism for electing president and vice president is necessary to hold elections with a combination of variety models. Conversely, if that is not possible and beyond the term of office of the president who served at that time, then the last option is to extend the term of office of the president temporarily.

Keywords: State of Emergency; Etat De Siege; Extended Presidential Term of Office; Election Variety Model.

\begin{abstract}
Abstrak
Keadaan darurat (state of emergency) seperti pandemi atau perang menghambat penyelenggaraan negara tidak dapat maksimal dilakukan, seperti pemilihan umum secara langsung. Oleh karena itu, dibutuhkan hukum tata negara darurat sebagai prevensi atas keadaan darurat (state of emergency) terutama mengenai pengisian jabatan presiden dan wakil presiden Ketentuan keadaan darurat sangat diperlukan di tengah ancaman pandemi di masa depan dan posisi geografis Indonesia yang rawan bencana berpotensi menghalangi proses suksesi kepemimpinan melalui pemilihan langsung. Tulisan ini dibahas secara yuridis-normatif berdasar asas-asas hukum dan ditulis secara deskriptif. Disimpulkan bahwa, ketika keadaan darurat negara telah ditetapkan, maka mekanisme pengisian jabatan presiden dan wakil presiden maka perlu diadakan pemilu dengan gabungan variasi model. Sebaliknya, jika hal tersebut tidak memungkinkan dan melampaui masa jabatan presiden yang menjabat saat itu, maka pilihan terakhir adalah memperpanjang masa jabatan presiden untuk sementara waktu. Kata Kunci: Keadaan Darurat; Hukum Tata Negara Darurat; Variasi Pemilu Presiden; Pengisian Jabatan Presiden.
\end{abstract}

Copyright (C) 2021 Universitas Airlangga 


\section{Pendahuluan}

Gelombang Reformasi 1998 di Indonesia telah membawa semangat demokratisasi kehidupan bernegara. Salah satu hasilnya adalah diselenggarakannya pemilihan langsung Presiden dan Wakil Presiden secara periodik lima tahunan. Saat ini, Pandemi Covid-19 telah mengubah paradigma pelaksanaan demokrasi di dunia, terutama pemilu. Jamak di berbagai negara dan Indonesia sendiri melakukan penundaan pemilu akibat Pandemi Covid-19 yang tidak memungkinkan mengadakan pemilu secara langsung.

Pembahasan artikel ini akan menjawab beberapa pertanyaan. Pertama, bagaimana pengaturan keadaan darurat di Indonesia. Kedua, bagaimana pelaksanaan pemilu saat keadaan darurat. Terakhir, bagaimana mekanisme pengisian jabatan presiden saat tidak terlaksananya pemilu hingga mengakibatkan kekosongan kekuasaan. Pertanyaan-pertanyaan ini muncul dikarenakan pengaturan mengenai hal tersebut belum diakomodasi di dalam UUD 1945 maupun UndangUndang. Tulisan ini dibahas menggunakan metodologi yuridis-normatif membahas berdasarkan konsep asas hukum dan sistematika hukum yang dibahas dengan pendekatan kualitatif dan dituangkan hasilnya secara deskriptif.

Untuk menjawab rumusan masalah di atas pembahasan dibagi menjadi lima bagian. Bagian pertama membahas mengenai HTN Darurat dan ketentuan keadaan darurat di Indonesia. Bagian kedua menjelaskan pengaturan masa jabatan dan mekanisme pengisian jabatan Presiden. Bagian ketiga menguraikan variasi model pelaksanaan pemilu dalam keadaan darurat. Bagian keempat pembahasan akan ditutup dengan usulan mekanisme pengisian jabatan Presiden saat keadaan darurat. Terakhir, pembahasan akan ditutup dengan peran Mahkamah Konstitusi dalam pengawasan mekanisme pengisian jabatan Presiden.

\section{Hukum Tata Negara Darurat (State of Emergency)}

Konsep Hukum Tata Negara Darurat (HTN Darurat) memiliki berbagai padanan antara lain noodstaatsrecht, state of emergency, state of exception, etat 
de siege, dan keadaan darurat. ${ }^{1}$ Sebagian sarjana hukum tidak mengartikan HTN Darurat sebagai staatsnoodrecht, melainkan dipadankan dengan noodstaatsrecht. Istilah staatsnoodrecht lebih menunjukkan hak negara dalam keadaan darurat atau HTN Darurat dalam arti subjektif. Sedangkan, istilah noodstaatsrecht berarti hukum yang berlaku disaat keadaan darurat atau HTN Darurat dalam arti objektif dan menjadi antonim dari staatsnoodrecht. Dengan demikian, HTN Darurat berbicara tentang hukum tata negara yang berlaku saat keadaan darurat berlangsung. ${ }^{2}$

Justifikasi keadaan darurat, yaitu berupa timbulnya keadaan-keadaan yang luar biasa dibanding keadaan normal sebagaimana biasanya. Menurut Scheppele, keadaan darurat situasi ketika negara harus menyelamatkan dirinya dengan bertindak cepat disaat menghadapi ancaman yang sedemikian serius dan ekstrim, tetapi tidak mungkin dilakukan sesuai dengan prinsip-prinsip yang dianut negara tersebut. ${ }^{3}$ Keperluan (necessity) untuk menyimpangi prinsip negara di atas menegaskan adanya pengecualian (exception) terhadap prinsip yang biasa diterapkan pada keadaan normal ketika terjadi keadaan darurat. Oleh karena itu, keadaan darurat juga dipahami sebagai state of exception karena penyelenggaraan negara saat keadaan darurat dilakukan dengan mengecualikan hukum biasa dalam keadaan normal. Akibatnya, hukum yang berlaku menyimpangi ketentuan peraturan perundangundangan sebagaimana yang berlaku dalam keadaan normal.

Pada awalnya, negara dikonstruksikan memiliki kepentingan berupa keperluan (necessity) untuk menyelamatkan dirinya ketika berhadapan dengan keadaan darurat. Sebab, keutamaan negara adalah stabilitasnya dan jika tidak segera diselamatkan negara akan hancur hanya karena terkungkung oleh hukum yang restriktif. ${ }^{4}$ Oleh karena itu, negara dapat bertindak apapun dan dengan cara apapun untuk menyelamatkan dirinya (self-preservation) termasuk berupa

\footnotetext{
Jimmly Asshisiddiqie, Hukum Tata Negara Darurat (Rajawali Press 2007).[7-8].

ibid.[18-19].

3 Kim Lane Scheppele, 'The Law in the Time of Emergency: States of Exception and the Temptations of 9/11' (2003-2004) 6 Journal of Constitutional Law.[1004].

4 Clement Fatovic, Outside the Law Emergency and Executive Power (John Hopkins University Press 2009). [40].
} 
tindakan ekstra legal (knows no law). ${ }^{5} \quad$ Berangkat dari keperluan (necessity) kemudian berkembang menjadi pembelaan diri negara (self-defence). Berbeda dengan necessity yang lebih bebas, tindakan membela diri harus disertai dengan batasan dan pedoman. ${ }^{6}$ Batasan tersebut ditegaskan oleh Krabbe yang berpendapat, meskipun hukum yang abnormal berlaku saat keadaan yang abnormal pula, tetapi tindakan ketika keadaan darurat harus wajar (standard of reasonableness) dan proporsional serta tak berlebihan. ${ }^{7}$

Oleh karena itu, ada beberapa kualifikasi untuk menetapkan keadaan darurat. Pertama, terdapat 3 unsur suatu keadaan dikatakan darurat, yaitu unsur kewajaran kebutuhan hukum (reasonable necessity), unsur keterdesakan (limited time) dan unsur bahaya yang mengancam (dangerous threat). ${ }^{8}$ Kedua, harus dipastikan bahwa penetapan keadaan darurat merupakan upaya terakhir dan tidak ada kemungkinan akan pilihan lain selain daripada menerapkan hukum dalam keadaan darurat tersebut (last resort). ${ }^{9}$ Oleh karenanya, diperlukan konsep constitutional dualism berupa adanya dua ketentuan hukum tata negara, yaitu hukum yang diterapkan dalam keadaan normal dan keadaan darurat. ${ }^{10}$

Keadaan darurat atau state of emergency harus dinyatakan secara terbuka agar diketahui umum. ${ }^{11}$ Pernyataan tersebut dilakukan guna mengetahui mulai berlakunya hukum luar biasa, yakni HTN Darurat dan mengetahui kapan akan berakhirnya. Pernyataan keadaan darurat sangat penting sebab negara diperbolehkan menyimpang dari asas-asas hukum yang umum saat keadaan darurat. ${ }^{12}$

\footnotetext{
${ }^{5}$ Diane A Desierto, Necessity and National Emergency Clauses: Sovereignty in Modern TreatyInterpretation (BRILL 2012).[69-70].

${ }^{6}$ Paul Leicester Ford, The Writings of Thomas Jefferson (GP Putnam's Son 1893).[278-279].

${ }^{7}$ Oren Gross dan Fionnuala Ni Aqlain, 'Emergency, War, and International Law'(2001) 70 Nordic Journal Of International Law.[35].

8 Jimmly Asshisiddiqie, Op.Cit.[64-65].

9 Jimmly Asshisiddiqie, Op.Cit.[64-65].

${ }^{10}$ John Ferejohn dan Pasquale Pasquino, 'The Law of the Exception; A Typology of Emergency Powers' (2004), 2 International Law Journal of Constitutional Law.[234].

11 Jimmly Asshisiddiqie, Op.Cit.[98].

12 Undang-Undang Nomor 12 Tahun 2005 tentang Pengesahan International Covenant on Civil and Polical Rights (Kovenan Internasional tentang Hak-Hak Sipil dan Politik) (Lembaran Negara Nomor 119 Tahun 2005).
} 


\section{Hukum Tata Negara Darurat di Indonesia}

Pengaturan keadaan darurat di Indonesia tertuang dalam UUD 1945 dan dalam beberapa undang-undang terkait dengan keadaan darurat. Di dalam UUD 1945, keadaan darurat diatur pada Pasal 12 dengan pilihan terminologi hukum "keadaan bahaya". Sebenarnya, pilihan terminologi "keadaan bahaya" tidak berbeda dengan istilah "keadaan darurat", karena keadaan bahaya juga menunjukkan suatu sifat kondisi adanya ancaman yang membahayakan (dangerous threat). ${ }^{13}$ Kewenangan pelaksana keadaan darurat di Indonesia berada pada Presiden selaku kepala negara. Namun, kewenangan tersebut dibatasi dengan undang-undang sebagai aturan lebih lanjut dari UUD 1945.

Pengaturan keadaan darurat juga diatur dalam Pasal 22 UUD 1945 tentang penerbitan Perpu karena "ihwal kegentingan memaksa". Keduanya dapat dikualifikasikan sebagai keadaan darurat karena baik keadaan bahaya dan Perpu, keduanya ditetapkan karena adanya kebutuhan yang beralasan (reasonableness necessity) yang wajib secepatnya dipenuhi (limited time). ${ }^{14}$ Persamaan lainnya yaitu setiap keadaan bahaya pasti memenuhi unsur "genting dan memaksa" layaknya penetapan Perpu. Sebaliknya, Pasal 12 dan Pasal 22 UUD 1945 memiliki perbedaan cukup prinsipil. Kedua pasal tersebut divergen dalam hal sifat ancaman yang membahayakan (dangerous threat), dimana hanya dimiliki oleh keadaan bahaya saja dan tidak demikian oleh Perpu. Selain itu, keadaan bahaya dipahami sebagai suatu struktur keadaan darurat, sedangkan alasan "ihwal kegentingan memaksa" dalam Perpu adalah isi dari keadaan bahaya tersebut. Selanjutnya, Perpu ditetapkan presiden tanpa harus disertai atau didahului dengan pernyataan keadaan bahaya. ${ }^{15}$

Indonesia memiliki beberapa undang-undang terkait keadaan darurat. Undang-undang yang mengatur keadaan bahaya adalah UU Prp Nomor 23 Tahun 1959. Pada undang-undang tersebut, keadaan darurat dibagi menjadi tiga jenis, yakni keadaan darurat sipil, keadaan darurat militer, dan keadaan darurat perang.

\footnotetext{
13 Jimmly Asshisiddiqie, Op.Cit.[206].

14 Mahkamah Konstitusi Republik Indonesia, Putusan Nomor 138/PUU-VII/2009.[18-20].

15 Mahkamah Konstitusi Republik Indonesia, Putusan Nomor 003/PUU-III/2005.[13-15].
} 
Namun, masing-masing jenis tidak diberikan pengertian yang cukup definitif untuk mengkualifikasi apa yang dimaksud keadaan darurat. Sehingga pengaturannya belum memadai dengan perkembangan keadaan darurat yang ada dan terasa old fashioned regulation. ${ }^{16}$ Selain itu, Indonesia memiliki pengaturan pengerahan umum ketika keadaan darurat yaitu melalui UU Nomor 27 Tahun 1997 tentang Mobilisasi dan Demobilisasi (UU Mobilisasi). ${ }^{17}$ Melalui UU Mobilisasi, diatur bahwa ketika terjadi dan ditetapkan keadaan bahaya maka dilakukan mobilisasi umum dan dilakukan demobilisasi jika keadaan telah pulih.

Berdasarkan uraian diatas, Indonesia belum memiliki dan mengakomodasi pengaturan keadaan darurat bentuk lainnya. Sebagai contoh, Indonesia belum mengatur bagaimana ketentuan proses demokrasi seperti suksesi kekuasaan ketika terjadi keadaan darurat baik perang atau keadaan darurat (emergency) lainnya. Oleh karena itu, dibutuhkan pengaturan normatif dalam rangka menyelesaikan kekosongan hukum tersebut.

\section{Pemilihan Presiden dan Masa Jabatan Presiden}

Reformasi 1998 telah membawa perubahan demokratisasi dalam hal pemilihan presiden secara langsung. Berdasarkan Pasal 6A UUD 1945 presiden dan wakil presiden dipilih oleh rakyat secara langsung melalui pemilihan umum. Mengenai pelaksanaan pemilu dalam keadaan darurat belum diatur di dalam pengaturan pemilu Indonesia. Saat ini, Indonesia hanya memiliki mekanisme penundaan pemilihan umum yang diatur dalam Undang-Undang No. 7 Tahun 2017 tentang Pemilihan Umum (Pemilu). ${ }^{18}$ Mekanisme penundaan pemilu menurut UU Pemilu dibagi menjadi dua, yakni Pemilu lanjutan dan Pemilu susulan.

\footnotetext{
${ }^{16}$ Fitra Arsil dan Qurrata Ayuni, 'Model Pengaturan Kedaruratan dan Pilihan Kedaruratan Indonesia Dalam Menghadapi Pandemi Covid-19’,(2020), 50 Jurnal Hukum dan Pembangunan. [429].

17 Undang-Undang Nomor 27 Tahun 1997 tentang Mobilisasi dan Demobilisasi (Lembaran Negara Nomor 75 Tahun 1997).

18 Undang-Undang Nomor 7 Tahun 2017 tentang Pemilihan Umum (Lembaran Negara Nomor 182 Tahun 2017).
} 
Tabel 1. Mekanisme Penundaan Pemilu

\begin{tabular}{|c|c|c|}
\hline & PEMILU LANJUTAN & PEMILU SUSULAN \\
\hline Pengaturan & Pasal 431 UU Pemilu & Pasal 432 UU Pemilu \\
\hline Sebab & $\begin{array}{l}\text { Di sebagian atau keseluruhan } \\
\text { wilayah Indonesia terjadi kerusuhan. } \\
\text { gangguan keamanan bencana } \\
\text { alam, atau gangguan lainnya yang } \\
\text { mengakibatkan sebagian tahapan } \\
\text { Penyelenggaraan Pemilu tidak } \\
\text { dapat dilaksanakan. }\end{array}$ & $\begin{array}{l}\text { Di sebagian atau keseluruhan wilayah } \\
\text { Indonesia terjadi kerusuhan. gangguan } \\
\text { keamanan bencana alam, atau gangguan } \\
\text { lainnya yang mengakibatkan seluruh } \\
\text { tahapan Penyelenggaraan Pemilu tidak } \\
\text { dapat dilaksanakan. }\end{array}$ \\
\hline Mekanisme & \multicolumn{2}{|c|}{ KPU mengeluarkan penetapan penundaan pelaksanaan pemilu. } \\
\hline Pelaksanaan & $\begin{array}{l}\text { Dimulai dari tahap Penyelenggaraan } \\
\text { Pemilu yang terhenti. }\end{array}$ & $\begin{array}{l}\text { Dilakukan untuk seluruh tahapan } \\
\text { penyelenggaraan Pemilu. }\end{array}$ \\
\hline $\begin{array}{l}\text { Syarat } \\
\text { Khusus }\end{array}$ & \multicolumn{2}{|c|}{$\begin{array}{l}\text { Jika Pemilu lanjutan atau Pemilu susulan tidak dapat dilaksanak } 40 \% \text { dari } \\
\text { jumlah provinsi dan } 50 \% \text { dari jumlah Pemilih terdaftar nasional tidak dapat } \\
\text { menggunakan hak pilihnya, maka penetapan Pemilu lanjutan atau Pemilu } \\
\text { susulan dilakukan oleh Presiden atas usul KPU. }\end{array}$} \\
\hline
\end{tabular}

Pengaturan tentang pemilu lanjutan dan susulan tidak memuat adanya pengaturan penundaan pemilu yang pelaksanaannya melewati batas pelantikan jabatan. Dengan demikian, diperlukannya pengaturan mengenai pelaksanaan tersebut.

Ketentuan mengenai pembatasan periode jabatan presiden dan wakil presiden ${ }^{19}$ dilakukan untuk menghindari periode jabatan tidak terbatas yang memberikan peluang besar terjadinya penyalahgunaan maupun penyelewengan kekuasaan. Terdapat adagium yang dikemukakan oleh Lord Acton "power tends to corrupt and the absolutely powers tends to corrupt absolutely" yang menyatakan bahwa sebuah penguasa cenderung korup dan kekuasaan absolut cenderung korup secara mutlak. Adagium tersebut menggambarkan penguasa saja bisa menyalahgunakan kekuasaannya, maka kekuasaan absolut akan lebih menyalahkan kekuasaan (abuse of power). ${ }^{20}$ Pembatasan masa jabatan Presiden merupakan upaya pencegahan terjadinya kekuasaan secara terus-menerus yang dapat diyakini menjadi dasar penyalahgunaan kekuasaan dan kewenangan.

\footnotetext{
${ }^{19}$ Undang-Undang Dasar Republik Indonesia Tahun 1945 Pasal 7.

${ }^{20}$ Micha Wiebusch dan Christina Murray, Presidential Term Limits and the African Union, 61 Journal of African Law (2019).[133-134].
} 


\section{Urgensi Pengaturan Pengisian Jabatan Presiden saat Keadaan Darurat}

Tatanan politik dunia yang selalu berubah secara cepat, memungkinkan munculnya perang di dunia. Saat ini, perebutan wilayah di Laut Cina Selatan antarnegara yang akan mengakibatkan ketidakstabilan keamanan di kawasan tersebut dapat berujung pada konflik terbuka. Keadaan ini dapat memicu konflik terbuka yang bisa menyeret Indonesia ke dalam sengketa tersebut. Hal ini dikarenakan Indonesia berletak dekat dengan Laut China Selatan. Meskipun sampai saat ini Indonesia sama sekali tidak pernah terlibat dengan permasalahan sengketa tersebut, tetapi Pulau Natuna yang merupakan wilayah zona ekonomi eksklusif (ZEE) Indonesia terletak di Laut China Selatan. ${ }^{21}$ Maka dari itu, wilayah Natuna yang berada di dekat Laut China Selatan berpotensi terpengaruh dinamika sengketa.

Selain urgensi perang dari wilayah Natuna, kondisi politik antara beberapa negara di dunia bisa menjadi pemicu terjadinya perang di Indonesia. Perseteruan antara Amerika Serikat (AS) dengan Korea Utara dalam bidang nuklir bisa menjadi salah satu pemicu munculnya keadaan perang di dunia. Keadaan tersebut dapat pula memicu Indonesia yang merupakan negara di wilayah Asia ikut terdampak perang..$^{22}$ Maka dari itu, Indonesia harus bersiaga dengan segala kemungkinan-kemungkinan perkembangan politik dunia.

Selanjutnya, pandemi Covid-19 telah membuka mata dunia bahwa peradaban manusia tidak akan lepas menghadapi pandemi lainnya yang tentunya sangat mungkin menyebar ke Indonesia melalui globalisasi dan interaksi internasional. Kemunculan pandemi SARS, ebola, nipah, MERS, H1N dua dekade terakhir memberikan pola umum bahwa manusia tidak akan lepas dari persoalan pandemi di kemudian hari. ${ }^{23}$ Ledakan penduduk dan kemajuan ekonomi menimbulkan

21 Dhiania Puspitawati, 'Sengketa Laut China Selatan dan Efeknya Bagi Indonesia', (Matamatapolitik.com, 2018) <https://www.matamatapolitik.com/in-depth-sengketa-laut-chinaselatan-dan-efeknya-bagi-indonesia/> diakses 28 Oktober 2020.

${ }^{22}$ Cahyo Prayogo, 'Jika AS dan Korut Perang Nuklir, Ini Dampak bagi Indonesia', (WartaEkonomi.co.id, 2017) <https:/www.wartaekonomi.co.id/read160644/jika-as-dan-korutperang-nuklir-ini-dampak-bagi-indonesia > diakses 29 Oktober 2020.

${ }^{23}$ [s.n.], Planning for the Next Global Pandemic, 38 Intenational Journal of Infectious Diseases (2005). [89]. 
peningkatan konsumsi seperti daging serta kebutuhan akan sumber daya lainnya. Akibatnya, dibangun peternakan secara masif dan pembukaan hutan untuk industri yang akhirnya mengganggu ekosistem hewan liar. ${ }^{24}$ Realita tersebut memperlebar probabilitas terjadinya pandemi, karena virus penyebab pandemi seringkali dibawa atau ditransmisikan dari hewan $\operatorname{liar}^{25}$ atau hewan ternak kepada manusia. ${ }^{26}$ Ketika hutan telah rusak dan peternakan semakin menjamur maka interaksi dan intrusi hewan liar pada lingkungan hidup manusia tidak dapat dihindari lagi. ${ }^{27}$ Dengan demikian, Indonesia dan dunia akan terus berada dalam bayangan ancaman pandemi dan harus siap untuk menghadapi situasi tersebut.

Indonesia memiliki potensi bencana alam yang beragam dan mengancam keselamatan karena posisinya berada di ring of fire atau cincin api pasifik. Bencana alam yang berpotensi besar terjadi di Indonesia adalah marine hazard, gempa bumi, tsunami, gunung meletus, hingga badai seperti El Nino dan La Nina. ${ }^{28}$ Indonesia rawan akan bencana karena pada incin api pasifik merupakan pertemuan dari 3 lempeng yang secara aktif bergerak sehingga menimbulkan aktivitas tektonik. ${ }^{29}$ Bahkan menurut perkiraan, Indonesia akan mengalami tsunami setinggi 20 meter yang tentunya sangat mengkhawatirkan dan diperlukan mitigasi sedini mungkin. ${ }^{30}$

${ }^{24}$ Ned Potter, How Animals Transmit Disease to Humans, (ABC News, 2006), <https:// abcnews.go.com/WNT/story?id=129546\&page=1> dikunjungi 1 November 2020 .

25 ibid.[93].

26 Jonathan Chan dan Sony Salzman, As Covid-19 Continues, Experts Warn of Next Pandemic Likely to Come from Animal. (ABC News 2020), $<$ https://abcnews.go.com/Healt h/ covid-19-continues-experts-warn-pandemic-animals/story?id=72755696 $>$ dikunjungi 1 November 2020.

27 Aritz Parra dan Mike Corder, Scientists Study Coronovirus Outbreaks Among Minks in Europe, (ABC News 2020), <https://abcnews.go.com/Health/wireStory/scientists-studycoronavirus-outbreaks-minks-europe-72130393> dikunjungi 1 November 2020.

28 Institut Teknologi Bandung, Mengelola Risiko Bencana di Negara Maritim Indonesia (Lembaga Penelitian dan Pengabdian Masyarakat ITB 2017).[3-5]. Diunduh dari https://www.lppm. itb.ac.id/wp-content/uploads/sites/55/2017/10/Buku_I.pdf.

29 Zulfikar Abbany, 'Volcanoes and Eearthquakes: The Pacific Ring of Fire' (DW 2020), < https://www.dw.com/en/volcanoes-and-earthquakes-the-pacific-ring-of-fire/a-36676363> dikunjungi 1 November 2020.

30 Yuni Astutik, Potensi Tsunami 20 Meter itu Nyata, Tapi Tak Perlu Panik (CNBC Indonesia 2020), < https://www.cnbcindonesia.com/news/20200929104447-4-190185/potensi-tsunami-20-meter-itu-nyata-tapi-tak-perlu-panik> dikunjungi 1 November 2020. 


\section{Komparasi Masa Jabatan Presiden saat Keadaan Darurat}

Mekanisme memperpanjang (extended) masa jabatan Presiden saat terjadi perang atau keadaan bahaya lainnya jamak diterapkan oleh negara lain. Secara umum, negara-negara yang menerapkan mekanisme perpanjangan masa jabatan presiden menggunakan alasan terbatas karena adanya perang dan keadaan bahaya lainnya (state of emergency). Negara-negara tersebut, diantaranya Sierra Leone, Tanzania, Seychelles, Afghanistan, dan Serbia.

Keputusan untuk memperpanjang masa jabatan presiden dilakukan dengan persetujuan parlemen. Konstitusi dari kelima negara, yaitu Sierra Leone, ${ }^{31}$ Tanzania, ${ }^{32}$ Seychelles, ${ }^{33}$ Afghanistan, ${ }^{34}$ dan Serbia, ${ }^{35}$ mengharuskan bahwa perpanjangan masa jabatan presiden diputuskan dengan resolusi dari parlemen. Dukungan yang disyaratkan untuk meluluskan resolusi tersebut beragam batas minimalnya, mulai dari $50 \%+1$ hingga $2 / 3$ suara dari parlemen. Dengan demikian, praktik kenegaraan di negara lain sangat memperhitungkan kedudukan parlemen bahkan ketika keadaan bahaya mengancam. Oleh karena itu, peran parlemen sebagai lembaga perwakilan rakyat dipertahankan untuk mengawasi eksekutif.

Perpanjangan masa jabatan presiden disertai dengan alasan yang terbatas dan ada syarat khusus. Meskipun kebanyakan jenis keadaan bahaya yang digunakan sebagai alasan perpanjangan adalah perang, tetapi keadaan bahaya lain juga masih diperhatikan. Serbia, Tanzania, dan Sierra Leone adalah contoh negara yang secara khusus mensyariatkan perang sebagai satu-satunya alasan untuk memperpanjang masa jabatan presiden. Sebaliknya, Seychelles dan Serbia masih memungkinkan perpanjangan masa jabatan presiden karena keadaan bahaya lainnya selain perang. Selanjutnya, terdapat syarat khusus untuk memperpanjang masa jabatan presiden yakni timbulnya kesulitan (difficult) mengadakan pemilu ketika keadaan bahaya sebagaimana diterapkan di Tanzania dan Sierra Leone.

\footnotetext{
${ }^{31}$ The Constitution of the Republic of Sierra Leone (Amended 2013). Artikel 49 dan 85.

32 The Constitution of the Republic of Tanzania (Amended 2005). Artikel 42 dan 90.

${ }^{33}$ The Constitution of the Republic of Seychelles (Amended 2017). Artikel 56 (6).

${ }^{34}$ The 2004 Constitution of the Islamic Republic of Afganistan.

35 The 2006 Constitution of the Republic of Serbia. Artikel 116.
} 
Berdasarkan pengalaman negara lain, perpanjangan masa jabatan juga dimungkinkan pada badan parlemen. Dengan ketentuan yang hampir sama dengan perpanjangan masa jabatan presiden, beberapa negara menerapkan perpanjangan masa jabatan parlemen karena adanya perang atau keadaan bahaya lainnya. Negara tersebut diantaranya, Maladewa, ${ }^{36}$ Uganda, ${ }^{37}$ Mauritius, ${ }^{38}$ dan Malta. ${ }^{39}$

\section{Solusi Pertama: Pemungutan Suara Pemilu}

Ketika presiden menyatakan keadaan darurat, maka pemilihan umum presiden dan wakil presiden semaksimal mungkin dilakukan dengan variasi model pemungutan suara pemilu demi menghindari perpanjangan masa jabatan. Sehingga pemungutan suara dilakukan dengan berbagai variasi disesuaikan dengan kondisi yang ada. Keadaan bahaya dapat berbahaya bagi demokrasi di sebuah negara, misalkan dengan mengesampingkan pelaksanaan pemilu konvensional, seperti penggunaan kertas suara dan/atau pelaksanaan langsung di tempat pemungutan suara (TPS). Selain sistem konvensional sebagaimana yang Indonesia gunakan saat ini, berikut variasi model pemungutan suara khusus dapat berupa: (a) pemungutan suara jarak jauh melalui pos; (b) pemungutan suara dengan mekanisme jemput bola; maupun (c) mekanisme pemungutan suara dengan jangka waktu yang lama.

Pertama adalah pemungutan suara jarak jauh melalui pos atau dapat disebut model pos. Model pos dilakukan dengan cara panitia pemilu mengirimkan kertas suara kepada calon pemilih melalui jasa pos dan setelah dilaksanakan pencoblosan, kertas suara tersebut dikirimkan lagi kepada panitia pemilu. Mekanisme ini sudah sering dilaksanakan oleh pemerintah Indonesia dalam penyelenggaraan pemilu untuk WNI yang berada di luar negeri. Selain itu, di Inggris, pemilih menggunakan hak suara melalui pos dengan syarat sedang berada jauh dari rumah, maupun

${ }^{36}$ The Constitution of the Republic of Maldives. Artikel 80.

37 The Constitution of the Uganda (Amended 2017). Artikel 77.

38 The Constitution of the Republic of Mauritius (Amended 2016). Artikel 57.

39 The Constitution of the Republic of Malta (Amended 2016). Artikel 76 (3). 
sedang berada di luar negeri. ${ }^{40}$ Kelebihnnya, model pos menjadi solusi ketika pemungutan suara tidak dapat dilaksanakan secara fisik. Selain itu, mekanisme ini dapat dilakukan secara jarak jauh (remote). Akan tetapi, mekanisme ini juga memiliki kekurangan, seperti pengeluaran biaya menjadi lebih mahal dan membutuhkan waktu yang lebih lama.

Variasi kedua adalah pemungutan suara dengan mekanisme jemput bola. Jemput bola adalah proaktif untuk menyelesaikan (tentang masalah). ${ }^{41}$ Dengan demikian, dapat dikonstruksikan lembaga penyelenggara pemilu yang berperan aktif dalam pelaksanaan pemilu dengan cara mendatangi calon pemilih ke rumahrumah untuk melakukan pemungutan suara, sehingga calon pemilih bisa langsung menggunakan hak suara mereka di rumah. Mekanisme jemput bola dalam pemilu sudah disarankan sejak tahun 2013 oleh Badan Pengawas Pemilu (Bawaslu) kepada Komisi Pemilihan Umum (KPU) saat partisipasi pemilih di Luar Negeri rendah. ${ }^{42}$ Mekanisme ini dapat dilaksanakan dalam keadaan darurat dengan tetap memperhatikan keamanan legitimasi penyelenggaraan pemilu. Namun, tetap ada hambatan dalam pelaksanaan mekanisme ini, yakni dibutuhkan lebih banyak tenaga sumber daya manusia selaku panitia pemilu. Selain itu, dikarenakan penduduk Indonesia yang besar, maka mekanisme ini sangat memakan waktu yang lama.

Terakhir adalah pemungutan suara dengan jangka waktu yang panjang. Selama ini, pemilu di Indonesia dilaksanakan serentak pada satu hari yang sama. Namun, dalam keadaan bahaya sukar pelaksanaan pemilu tersebut dalam waktu serentak. Variasi jangka waktu panjang ini dikonstruksikan dengan pelaksanaan pemilu yang bisa dibagi ke beberapa tahap, misalnya tahap pertama pemungutan suara di Pulau Sumatera, tahap kedua di Pulau Jawa, tahap ketiga di Pulau Kalimantan, dan tahap-tahap selanjutnya. Pelaksanaan pemungutan suara dengan jangka waktu

\footnotetext{
${ }^{40}$ [s.n], 'How to Vote', (Gov.UK, [s.a]) < https://www.gov.uk/voting-in-the-uk/postal-voting > dikunjungi 28 Oktober 2020.

${ }^{41}$ KBBI, 'Pengertian Jemput Bola', (Kamus Besar Bahasa Indonesia versi Daring, [s.a]) $<$ https://kbbi.web.id/jemput-2> dikunjungi 28 Oktober 2020.

${ }^{42}$ [s.n], 'Partisipasi Pemilih Luar Negeri Rendah, KPU Diminta Jemput Bola', (Kompas. com, 2013) <https://nasional.kompas.com/read/2013/08/15/1654458/Partisipasi.Pemilih.Luar.Negeri.Rendah.KPU.Diminta.Jemput.Bola> dikunjungi 28 Oktober 2020.
} 
sudah pernah dilaksanakan di India pada tahun 2019. ${ }^{43}$ Melihat kasus ini, yang disebabkan jumlah penduduk yang besar dan tantangan geografis di India, maka variasi pemungutan suara dengan jangka waktu panjang juga bisa diterapkan di Indonesia yang memiliki kesamaan faktor dengan India dalam hal jumlah penduduk yang besar dan tantangan geografis.

Variasi model pemungutan suara khusus dapat dilakukan untuk pemenuhan hak konstitusional warga negara dalam keadaan bahaya. Variasi tersebut tidak melanggar asas-asas pemilu yang sudah diatur dalam UUD $1945 .{ }^{44}$ Hal ini menjadikan variasi model khusus tersebut dapat dilaksanakan, walaupun variasi ini belum pernah dilaksanakan sebelumnya di Indonesia. Variasi tersebut bisa menjadi bahan pertimbangan pelaksanaan pemilu di Indonesia dalam keadaan bahaya. Dalam pelaksanaannya, probabilitas variasi model khusus ini bisa diterapkan tidak hanya terpaku pada satu model saja. Namun, beberapa variasi model dapat diterapkan secara bersamaan dalam kondisi tertentu. Hal ini dapat dilaksanakan sesuai dengan kondisi keadaan bahaya dan karakteristik geografis di Indonesia.

Pemerintah harus dengan sungguh-sungguh mengusahakan pelaksanaan pemilu dengan model yang beragam guna menghindari perpanjangan masa jabatan. Namun, apabila dinilai tetap tidak dapat dilaksanakan atau suatu alasan lain sehingga berakibat belum terpilihnya presiden hasil pemilu, maka solusinya adalah dengan memperpanjangan masa jabatan presiden selama beberapa waktu.

\section{Solusi Kedua: Perpanjangan Masa Jabatan Presiden}

Keadaan darurat yang telah dinyatakan oleh presiden (state of emergency) merupakan peristiwa luar biasa dan harus dipulihkan secara luar biasa pula (abnormale recht voor abnormale tijd). Oleh karena itu, penyimpangan terhadap prosedur pemilihan langsung presiden perlu (necessity) dan beralasan

\footnotetext{
${ }^{43}$ Nadim Asrar, 'India Votes in First of Seven-Phase General Election', (Aljazeera.com, 2019) < https://www.aljazeera.com/news/2019/4/11/india-votes-in-first-of-seven-phase-generalelection> dikunjungi 28 Oktober 2020.

${ }^{44}$ Undang-Undang Dasar 1945 Perubahan IV (Lembaran Negara Nomor 14 Tahun 2006), Ps. 22 E ayat (1).
} 
secara wajar (reasonableness) dilakukan. Sebab, jika tidak demikian akan terjadi kekosongan kekuasaan karena pemilu tidak diadakan dan presiden baru belum terpilih. Perpanjangan masa jabatan adalah upaya terakhir (last resort) ketika telah diusahakan pemilu dengan variasi, tetapi tidak pula dimungkinkan dilaksanakan. Dengan demikian, keputusan cepat (limited time) yang dapat diambil untuk terhindar dari kekosongan tersebut adalah memperpanjang masa jabatan presiden.

Perpanjangan masa jabatan terjadi ketika state of emergency terjadi karena suatu keadaan darurat. Rumusan umum yakni keadaan darurat akan mengakomodasi peristiwa-peristiwa bahaya yang mungkin saja belum dapat diperkirakan baik akibat atau bentuknya. Terlebih Indonesia memiliki potensi kebencanaan baik alam atau non-alam yang tinggi. Oleh karena itu, keberlakukan hukum saat keadaan bahaya tidak boleh mengekang tindakan-tindakan yang perlu (necessity) untuk memulihkan keadaan, tetapi sejauh mungkin harus diawasi oleh parlemen dan lembaga yudisial.

Setiap pernyataan keadaan bahaya tidak otomatis ditetapkan perpanjangan masa jabatan. Sebab, keadaan bahaya itu harus mengakibatkan pemungutan suara tidak dapat dilakukan di seluruh atau sebagian jumlah provinsi di Indonesia. Dengan demikian, perpanjangan masa jabatan hanya dilakukan jika ada pernyataan keadaan bahaya dan timbul syarat akibat yang dimaksud tersebut.

Akibat keadaan bahaya harus signifikan dan beralasan wajar (reasonableness) terhadap pelaksanaan pemilihan umum. Oleh sebab itu, setidaknya pemilu tidak dapat diadakan di seluruh atau sebagian jumlah provinsi. Ketentuan definit jumlah provinsi menjamin terpenuhinya signifikansi akibat keadaan bahaya dan mencegah penyalahgunaan alasan keadaan bahaya supaya terus menduduki kekuasaan.

Perumusan sebagian jumlah provinsi memberikan ruang penafsiran dari sudut pandang luas wilayah atau jumlah penduduk. Karena terdapat probabilitas pemilu tidak dapat diadakan di banyak provinsi, tetapi jumlah pemilihnya relatif kecil. Sebaliknya, mungkin pemilu tidak dapat dilaksanakan di sebuah 
provinsi, tetapi jumlah pemilihnya sangat besar. ${ }^{45}$ Mekanisme tersebut mencegah pengabaian hak pilih masyarakat di provinsi yang berpenduduk kecil. Selain itu, mekanisme tersebut dapat memberikan legitimasi politik yang kuat dan merata dari seluruh provinsi.

Setelah syarat pernyataan keadaan bahaya dan syarat akibat diatas telah terpenuhi, Presiden menyatakan perpanjangan masa jabatannya dengan persetujuan MPR. Maka, Presiden akan menjabat terus-menerus hingga terpilih presiden yang baru hasil pemilu dilantik. Perpanjangan tersebut bertujuan memberikan kesempatan bagi presiden untuk mengadakan pemilu dan terpilih presiden baru paling lambat 4 bulan dari waktu seharusnya masa jabatan presiden habis. Oleh karena itu, Presiden harus mempersiapkan dan mengadakan pemilu sesegera mungkin.

Namun, jika tetap gagal mengadakan pemilu setelah memaksimalkan seluruh variasi pemungutan suara, Presiden diberi hak memperpanjang masa jabatannya kembali atas persetujuan MPR. Bahkan perpanjangan bisa dilakukan sebanyak mungkin, tetapi setiap perpanjangan tidak boleh lebih dari 4 bulan dan jumlah total seluruh perpanjangan tidak lebih dari 12 bulan. Namun, untuk perpanjangan kedua dan seterusnya itu harus dengan persetujuan Mahkamah Konstitusi.

Persetujuan MPR pada setiap keputusan perpanjangan masa jabatan adalah bentuk pengawasan dan kontrol parlemen sebagai lembaga representasi rakyat terhadap keputusan Presiden. ${ }^{46}$ Meskipun keadaan bahaya berlangsung, tetapi peranan lembaga MPR untuk mengimbangi dan mengawasi kebijakan eksekutif sangat krusial terlebih ketika keadaan sedang tidak menentu. ${ }^{47}$ Selain itu, persetujuan MPR menjadi legitimasi politik perpanjangan masa jabatan Presiden karena tidak ada pemilu yang diadakan.

\footnotetext{
45 Dika Dania Kardi.[et.al],Sebaran Pemilih Untuk Pemilu 2019,(CNN Indonesia 2018) $<$ https://www.cnnindonesia.com/nasional/20180906140542-35-328163/sebaran-pemilih-untuk-pemilu-2019> dikunjungi 29 Oktober 2020.

46 Jimmy Asshiddiqe, Pengantar Hukum Tata Negara Jilid 2 (Sekretariat Jenderal dan Kepaniteraan Mahkamah Konstitusi 2006).[36].

47 Ibid.18].
} 


\section{Keadaan Darurat Perang (State of War)}

Potensi terjadinya perang di Indonesia dapat mempengaruhi kekuasaan eksekutif di Indonesia. Perpu Keadaan Bahaya mengklasifikasikan perang menjadi salah satu keadaan bahaya di Indonesia. Dengan adanya keadaan perang yang masih diklasifikasikan sebagai keadaan bahaya, maka penyelenggaraan pemilu sangat memungkinkan tidak dapat dilaksanakan. Perang sebagai salah satu sebab state of emergency menyulitkan penyelenggaraan pemilu, termasuk dengan berbagai model variasi. Alasannya, pertama, saat keadaan perang hak milik barang-barang semacam apapun yang berhubungan dengan kepentingan keamanan atau pertahanan menjadi milik negara. ${ }^{48}$ Kedua, kewajiban warga negara untuk turut serta dalam pertahanan negara. ${ }^{49}$ Ketiga, adanya mobilisasi rakyat yang tidak menjadi angkatan perang. ${ }^{50}$ Sehingga, ketiga faktor tersebut menimbulkan partisipasi rakyat dalam pemilu akan turun signifikan dan berdasarkan UU Mobilisasi, rakyat akan dikerahkan secara massal untuk pemenangan perang. Alasan-alasan tersebut menjadikan tidak dapat terlaksananya pemilu. Maka dari itu, harus ada mekanisme pengisian jabatan presiden saat keadaan perang, agar tidak terjadi kekosongan kekuasaan saat masa jabatan Presiden tersebut habis.

Terdapat beberapa opsi mengenai mekanisme pengisian jabatan presiden saat keadaan perang. Mekanisme pertama adalah perpanjangan masa jabatan presiden selama masa perang hingga perang selesai dan presiden baru harus terpilih sejak 4 (empat) bulan pernyataan perang selesai. Jika setelah 4 bulan belum dimungkinkan pemilihan presiden baru karena masa transisi dan pemulihan pasca perang, maka masa jabatan tersebut dapat diperpanjang lagi selamat 4 bulan dengan batas maksimal 48 bulan. Dalam pelaksanaan perpanjangan masa jabatan setelahnya, Presiden harus meminta persetujuan

48 Peraturan Pemerintang Pengganti Undang-Undang Nomor 23 Tahun 1959 tentang Pencaburan Undang-Undang Nomor 74 Tahun 1957 (Lembaran Negara Nomor 160 Tahun 1957) Dan Penetapan Keadaan Bahaya (Lembaran Negara Nomor 139 Tahun 1959), Ps. 37 ayat (1) dan (2).

49 Undang-Undang Nomor 3 Tahun 2002 tentang Pertahanan Negara Republik Indonesia (Lembaran Negara Nomor 4169 Tahun 2002). Ps. 2.

50 ibid. Penjelasan, Bab VI. Sifat Pertahanan. 
MPR selaku representasi rakyat dan pengajuan permohonan ke MK sebagai fungsi checks and balances lembaga yudisial.

\section{Fungsi Checks and Balances oleh Mahkamah Konstitusi}

Perpanjangan masa jabatan presiden karena perang atau keadaan bahaya lainnya harus tunduk pada ketentuan konstitusi sebagai sumber atribusi dan legitimasinya. Bahwa pengaturan dalam keadaan bahaya (state of emergency) tidak boleh terlalu mengekang, tetapi sejauh mungkin tetap diawasi termasuk pada aspek konstitusionalitasnya dengan dibukanya peluang judicial review. ${ }^{51}$ Oleh karena itu, tugas menjamin kepatuhan konstitusi diberikan kepada Mahkamah Konstitusi (MK) sebab kedudukannya sebagai the guardian of the constitution. ${ }^{52}$ Maka, wibawa konstitusi sebagai sumber legitimasi perpanjangan masa jabatan tidak boleh dikesampingkan hanya karena keadaan bahaya. ${ }^{53}$ Selain itu, mekanisme penglibatan MK mencegah terjadinya penyalahgunaan keadaan bahaya untuk kepentingan diluar tujuan mengadakan pemilu. Selain itu, hakikat keadaan bahaya adalah bersifat sementara, maka perpanjangan masa jabatan juga harus bersifat sementara.

Keterlibatan MK di dalam masalah perpanjangan masa jabatan, yaitu memutus permohonan dari Presiden untuk memperpanjang masa jabatan kedua dan seterusnya. MK tidak terlibat ketika keputusan perpanjangan masa jabatan pertama kali dilakukan. Permohonan itu akan dinilai oleh MK berdasarkan fakta bahwa Presiden telah bersungguh-sungguh mempersiapkan pemilu, namun karena suatu alasan yang wajar (reasonableness) pemilu belum dapat diadakan sehingga perlu diperpanjang kembali masa jabatan presiden yang bersangkutan. Permohonan dari Presiden kepada MK tersebut harus diajukan oleh Presiden dan diputuskan oleh MK pada suatu waktu yang tidak saling berjauhan dan tidak terlalu lama dari waktu

\footnotetext{
${ }^{51}$ Jimmly Asshiddiqie, Hukum Acara Pengujian Undang-Undang (Yasrif Watampone 2004).[1]

52 Ilham Yuli Isdianto, Mahkamah Konstitusi Sebagai The Guardian of the Constitution (Fakultas Hukum UII 2012).

53 Jimmly Asshisiddiqie, Op.Cit.[265].
} 
habis masa jabatan presiden dari perpanjangan pertama kali. Diharapkan adanya persetujuan MK akan mendorong Presiden bersungguh-sungguh untuk mengadakan pemilu dan memperhitungkan dengan cermat segala kebijakan yang diambil.

Setiap pernyataan perpanjangan masa jabatan dapat diajukan pengujian (judicial review) kepada MK oleh setiap warga negara Indonesia (WNI). Pengujian dilakukan guna menilai apakah telah memenuhi syarat akibat, yaitu syarat keadaan bahaya menimbulkan tidak dapat diadakannya pemungutan suara di seluruh atau sebagian jumlah provinsi di Indonesia. Selain itu, berhubung perpanjangan masa jabatan yang pertama kalinya tidak diperlukan persetujuan MK, maka hak pengujian oleh warga negara ini menjadi sarana melihat konstitusionalitas pernyataan perpanjangan tersebut. Kemudian Presiden juga diharapkan berhatihati sejak pernyataan perpanjangan masa jabatan yang pertama karena sejatinya MK berfungsi untuk mencegah campur tangan kepentingan politik yang melanggar konstitusi. ${ }^{54}$ Oleh karena itu, Presiden dan MPR diharapkan mempertimbangkan aspek hukum dan konstitusi selain aspek politik dalam mengambil keputusan perpanjangan masa jabatan.

\section{Kesimpulan}

Berdasarkan pembahasan di atas, dapat disimpulkan beberapa hal berikut. Pertama, Indonesia belum memiliki pengaturan mengenai keadaan darurat (state of emergency) yang memadai terutama ketika keadaan darurat bertepatan dengan suksesi jabatan presiden. Kedua, terdapat beberapa variasi model pemungutan suara sebagai langkah final mengisi jabatan presiden secara demokratis layaknya keadaan normal saat terjadi keadaan darurat. Ketiga, jika prosedur pengisian jabatan presiden secara demokratis tidak dapat dilaksanakan, masa jabatan presiden diperpanjang untuk sementara waktu demi menghindari kekosongan jabatan presiden. Namun, tetap dengan pengawasan dari MPR selaku representasi rakyat dan MK sebagai bentuk fungsi checks and balances lembaga yudisial.

\footnotetext{
${ }^{54}$ Moh. Mahfud MD, Demokrasi dan Konstitusi di Indonesia: Studi tentang Interaksi Politik dan Kehidupan Ketatanegaraan (Rineka Cipta 2000).[37].
} 
Berdasarkan hasil pembahasan di atas, kami merekomendasikan beberapa usulan pengaturan untuk dimasukkan ke dalam perubahan Pasal 12 UUD 1945 mengenai keadaan bahaya (state of emergency) guna mengakomodasi mekanisme pengisian jabatan presiden saat terjadi state of emergency, yaitu:

1. Modifikasi model pemungutan suara demi menghindari perpanjangan masa jabatan presiden, seperti pemungutan suara jarak jauh melalui pos, model jemput bola, dan/atau pemungutan suara dengan jangka waktu yang panjang.

2. Perpanjangan masa jabatan presiden atas persetujuan MPR saat state of emergency selain perang. Perpanjangan dapat dilakukan sebanyak mungkin, tetapi setiap perpanjangan tidak boleh lebih dari 4 bulan dan jumlah total seluruh perpanjangan tidak lebih dari 12 bulan. Namun, untuk perpanjangan kedua dan seterusnya itu harus dengan persetujuan Mahkamah Konstitusi.

3. Perpanjangan masa jabatan presiden atas persetujuan MPR saat keadaan perang. Perpanjangan masa jabatan presiden selama masa perang hingga perang selesai dan presiden baru harus terpilih sejak 4 (empat) bulan pernyataan perang selesai. Jika setelah 4 bulan belum dimungkinkan pemilihan presiden baru karena masa transisi dan pemulihan pasca perang, maka masa jabatan tersebut dapat diperpanjang lagi selamat 4 bulan dengan batas maksimal 48 bulan.

\section{Daftar Bacaan}

\section{Buku}

Clement Fatovic, Outside the Law Emergency and Executive Power (John Hopkins University Press 2009).

Diane A Desierto, Necessity and National Emergency Clauses: Sovereignty in Modern TreatyInterpretation (BRILL 2012).

Ilham Yuli Isdianto, Mahkamah Konstitusi Sebagai The Guardian of the Constitution, (Fakultas Hukum UII 2012).

Jimmly Asshisiddiqie, Hukum Tata Negara Darurat (Rajawali Press 2007).

Jimmy Asshiddiqe, Pengantar Hukum Tata Negara Jilid 2 (Sekretariat Jenderal dan Kepaniteraan Mahkamah Konstitusi 2006). 
Jimmly Asshiddiqie, Hukum Acara Pengujian Undang-Undang (Yasrif Watampone 2004).

Moh. Mahfud MD, Demokrasi dan Konstitusi di Indonesia: Studi tentang Interaksi Politik dan Kehidupan Ketatanegaraan (Rineka Cipta 2000).

Paul Leicester Ford, The Writings of Thomas Jefferson, (GP Putnam's Son 1893).

\section{Jurnal}

Fitra Arsil dan Qurrata Ayuni, 'Model Pengaturan Kedaruratan dan Pilihan Kedaruratan Indonesia Dalam Menghadapi Pandemi Covid-19',(2020), 50 Jurnal Hukum dan Pembangunan.

John Ferejohn dan Pasquale Pasquino, 'The Law of the Exception; A Typology of Emergency Powers' (2004), 2 International Law Journal of Constitutional Law.

Kim Lane Scheppele, 'The Law in the Time of Emergency: States of Exception and the Temptations of 9/11'(2003-2004), 6 Journal of Constitutional Law.

Micha Wiebusch dan Christina Murray, Presidential Term Limits and the African Union, 61 Journal of African Law (2019).

Oren Gross dan Fionnuala Ni Aqlain, 'Emergency, War, and International Law'(2001) 70 Nordic Journal of International Law.

\section{Laman}

[s.n], 'How to Vote', (Gov.UK, [s.a]) < https://www.gov.uk/voting-in-the-uk/postalvoting $>$ diakses 28 Oktober 2020.

KBBI, 'Pengertian Jemput Bola', (Kamus Besar Bahasa Indonesia versi Daring, [s.a]) <https://kbbi.web.id/jemput-2> diakses 28 Oktober 2020.

[s.n], 'Partisipasi Pemilih Luar Negeri Rendah, KPU Diminta Jemput Bola', (Kompas.com, 2013) < https://nasional.kompas.com/read/2013/ 08/15/1654458/Partisipasi.Pemilih.Luar.Negeri.Rendah.KPU.Diminta. Jemput.Bola $>$ diakses 28 Oktober 2020.

Dika Dania Kardi.[et.al],Sebaran Pemilih Untuk Pemilu 2019,(CNN Indonesia 2019) < https:// www.cnnindonesia.com/nasional/20 180906140542-35-328 163/sebaran-pemilih-untuk-pemilu-2019> dikunjungi 29 Oktober 2020.

Dhiania Puspitawati, 'Sengketa Laut China Selatan dan Efeknya Bagi Indonesia', (Matamatapolitik.com, 2018) <https://www.matamatapolitik.com/in-depthsengketa-laut-china-selatan-dan-efeknya-bagi-indonesia/> diakses 28 Oktober 2020. 
Nadim Asrar, 'India Votes in First of Seven-Phase General Election', (Aljazeera. com, 2019) <https://www.aljazeera.com/news/201 9/4/11/india-votes-infirst-of-seven-phase-general-election $>$ dikunjungi 28 Oktober 2020.

\section{Perundang-undangan}

Undang-Undang Dasar Republik Indonesia Tahun 1945.

Peraturan Pemerintang Pengganti Undang-Undang Nomor 23 Tahun 1959 tentang Pencaburan Undang-Undang Nomor 74 Tahun 1957 (Lembaran Negara Nomor 160 Tahun 1957) Dan Penetapan Keadaan Bahaya (Lembaran Negara Nomor 139 Tahun 1959), Ps. 37 ayat (1) dan (2).

Undang-Undang Nomor 27 Tahun 1997 tentang Mobilisasi dan Demobilisasi Lembaran Negara Nomor 75 Tahun 1997 Tambahan Lembaran Negara Nomor 3704.

Undang-Undang Nomor 12 Tahun 2005 tentang Pengesahan International Covenant on Civil and Polical Rights (Kovenan Internasional tentang Hak-Hak Sipil dan Politik) (Lembaran Negara Nomor 119 Tahun 2005).

Undang-Undang Nomor 7 Tahun 2017 tentang Pemilihan Umum Lembaran Negara Nomor 182 Tahun 2017 Tambahan Lembaran Negara Nomor 6109.

\section{Putusan Mahkamah Konstitusi}

Mahkamah Konstitusi Republik Indonesia, Putusan Nomor 138/PUU-VII/2009.

Mahkamah Konstitusi Republik Indonesia, Putusan Nomor 003/PUU-III/2005. 
Aditya Wahyu: Gagasan Mekanisme Pengisian...

--halaman ini sengaja dibiarkan kosong-- 